\title{
Trustworthiness: The Core of Leadership in Islam
}

\author{
Nur Sofia Nabila Binti Alimin 1,*, Siti Rahmah Binti Awang ${ }^{2}$, Tahir Ahmad ${ }^{3}$, Jima 'ain Safar ${ }^{4}$ and Shukri Mohd Nain ${ }^{5}$ \\ 1,2, 5 Department of Human Resource Development, Faculty of Management, 81310 Universiti Teknologi Malaysia, Johor, Malaysia \\ ${ }^{3}$ Department of Mathematical Sciences, Institute Ibnu Sina, 81310 Universiti Teknologi Malaysia, Johor, Malaysia \\ ${ }^{4}$ 3Faculty of Islamic Civilization, 81310 Universiti Teknologi Malaysia, Johor, Malaysia
}

\begin{abstract}
This article discusses the concept of trustworthiness as the core of Islamic leadership as well as the crucial elements in trustworthiness in instilling this concept in the present leadership. Trustworthiness can be classified into two which are for Allah and for mankind. There are four elements under the classification for Allah which are Iman, Islam, Ihsan and Taqwa. Meanwhile, under the classification for mankind, there are four elements of trustworthiness. They are just, responsibility, integrity and accountability.
\end{abstract}

\section{Introduction}

\begin{abstract}
Allah describes trustworthiness methaphorically in ayah 72, Surah Al-Ahzab. Trustworthiness is an enormous weight; Allah's great creations such as the sky, the earth and the mountains are not able to carry its heaviness because they know when they betray trustworthiness, they are to be punished severely. However, men who are Allah's lesser creations are willing to carry the weight of trustworthiness. Indeed, there have been those who are severly punished by Allah due to the betrayal of trustworthiness. Those who are negligent in carrying trustworthiness are those who are tyrant and ignorant (Abidin, 2008).
\end{abstract}

"Indeed, we offered the Trust to the heavens and the earth and the mountains, and they declined to bear it and feared it; but man [undertook to] bear it. Indeed, he was unjust and ignorant." (Surah Al-Ahzab: 72).

Trustworthiness is about having the capabilities that match with the responsibility that one carries, and by not having trustworthiness, it could mean a disaster to ummah and the society. A disaster in the community system ruins individuals in general. Prophet Muhammad (pbuh) often reminded his ummah on the disaster in life if trustworthiness is betrayed. A leadership post needs trustworthiness; a person is required to choose the person for and to have ownership of the post based on a person's capabilities. If he or she does not do that, he or she is considered a traitor (Zainal Abidin, 2010). Hence, what is the fundamental for a person to choose and appoint a leader who is capable for a post? Based on Al Qasas Surah, Allah says:

"One of the women said, "O my father, hire him. Indeed, the best one you can hire is the strong and the trustworthy."(Surah Al Qasas, 28:26).

In this ayah, Prophet Moses was inherited with two attributes which were Al-Qawwiy (strong) and Al-Amanah (trustworthy). Therefore, the task or the responsibility of a post given to a person must be based on these two attributes. As stated by Syeikh al-Islam Ibn Taimiyyah in the as-Siyasah asy-Syar'iyyah fi Islah ar-Ra'i wa ar-Ra'i yyah, the two main attributes in Islamic leadership are Al-Quwwah which is the strength, the capability and the skill in carrying out a task or a responsibility and Al-Amanah which means can be trusted or responsible (having 
integrity and accountability). Both of these attributes are crucial for a true Muslim leader (Zainal Abidin, 2010). In this article, Amanah or trustworthiness will discussed as the core or the fundamental of leadership.

\section{Trustworthiness}

A Muslim thinker (Harun, 2013) has defined trustworthiness based on these following categories.

\subsection{Definition}

Based on Islamic leadership, trustworthiness refers to three things which are fear of Allah, not using Allah's ayahs to his or her own advantange and no fear of mankind. According to Kazmi \& Ahmad (2006), leadership in Islam centres on trustworthiness which it represents a psychological contract between leaders and their followers that they will try their best to guide, protect and treat their followers justly. Besides, a trustworthy leader is the one who is mindful of his or her relationship with Allah, is aware of the state of being the servant of Allah and being the caliph in this world. In addition, his or her main responsibility is to manage the world according to Allah's wants and to establish good relationship among mankind. In the book titled Syakhsiah al-Muslim al-Mu'asir by Syeikh Mustafa Muhammad at-Tohhan, several responsibilities of a leader have been outlined. Among them are to uphold Allah's syariat based on what have been ordered by Him, to uphold justice among people without any racial prejudice and is sensitive to the problems faced by his or subjects (Harun, 2013). Allah says,

"Allah has promised those who have believed among you and done righteous deeds that He will surely grant them succession [to authority] upon the earth just as He granted it to those before them and that He will surely establish for them [therein] their religion which He has preferred for them and that He will surely substitute for them, after their fear, security, [for] they worship Me, not associating anything with Me. But whoever disbelieves after that then those are the defiantly disobedient."(Surah an-Nur:55)

Hence, trustworthiness has elements which can be classified into for Allah (habluminnAllah) and for mankind (hablumminnanas). There are four components under the classification of trustworthiness which are just, responsibility, integrity and accountablility.

\subsection{Elements of Trustworthiness}

Trustworthiness can be classified into two which are for Allah and for mankind (Harun, 2013). There are four elements under the classification for Allah which are Iman, Islam, Ihsan and Taqwa (Beekun \& Badawi, 2004). Meanwhile, under the classification for mankind, there are four elements of trustworthiness. They are just, responsibility, integrity and accountability. Based on the Surah of An-Nisa, ayah 58, just has been chosen to be an element of being trustworthy (Mukred Mohsen, 2007), meanwhile Syeikh Ibnu Taimiyyah (Zainal Abidin, 2010) has stated that other elements of trustworthy are responsibility, integrity and accountability. These four elements are illustrated in Figure 1.

\subsubsection{Amanah to Allah}

Leadership in Islam is rooted in belief and willing submission to Allah. It focused on serving Him. The main tasks of leaders are to do good deeds and to work toward the establishment of way of living ordained by Allah (Beekun \& Badawi, 2004). Besides, Ahmad \& Fontaine (2011) mentioned that, a leader is not free to act as he or she chooses, nor must he send to the wishes of any group but he or she must act only to implement God's commands on Earth. As stated by ayah 73, Surah Anbiyaa, 
"And We made them leaders guiding (men) by Our command and We sent them inspiration to do good deeds, to establish regular prayers and to practice regular charity; and they constantly served Us (and Us only" (Surah Anbiyaa: 73).

There are four elements under the classification Amanah for Allah which are Iman, Islam, Taqwa dan Ihsan. The source of a leader's conviction in Allah's signs is his faith (yaqin) in Allah or Iman (Beekun \& Badawi, 2004; Kazmi \& Ahmad, 2006).

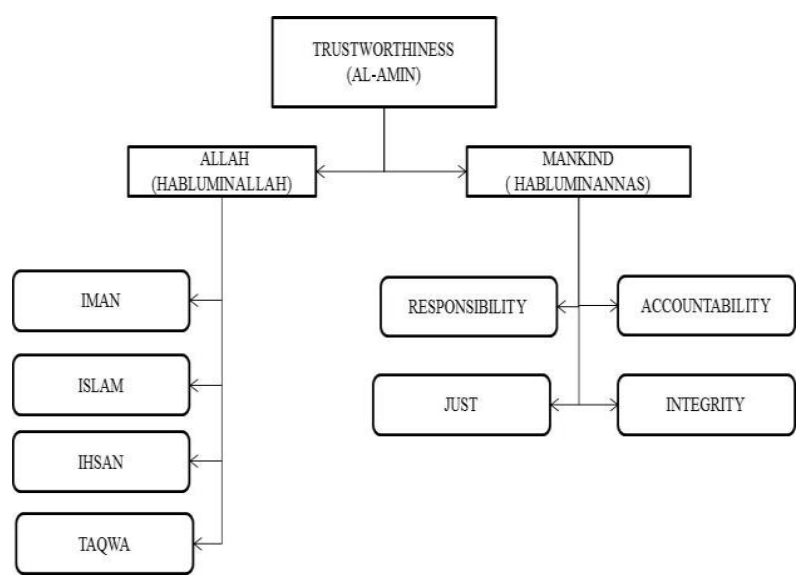

Fig. 1. Elements of Trustworthiness

\subsubsection{Iman}

Iman implies trust in the Oneness of Allah and the prophethood of Muhammad SAW. An individual with strong iman will consider himself and all his possessions as belonging to Allah. He will bow his ego, ideas, passions and thinking before Allah. A leader with firm Iman will take responsibility for his actions and will continuously emphasize on good deeds (Ahmad \& Fontaine, 2011).

\subsubsection{Islam}

The term Islam comes from the Arabic root "SLM" which refers to peace and submission. The achievement of peace with Allah, within oneself and with the creation of Allah, through willing submission to Him is the meaning of Islam (Beekun \& Badawi, 2004). The Prophet Muhammad SAW defined Islam as:

Islam implies that you testify that there is no God but Allah and that Muhammad is the messenger of Allah, and you establish prayer, pay Zakat, observe the fast of Ramadan, and perform pilgrimage to the (House) if you are solvent enough (to bear the expense of) the journey. (Sahih Muslim) (Khan, Farooq \& Hussain, 2010).

A leader who practices Islam will submit his ego to Allah and never see himself as supreme (Beekun \& Badawi, 2004).

\subsubsection{Ihsan}

Ihsan is an Arabic word that means excellence. The verb of ihsan is Hasona that refers to become good. Ihsan in Quran conveys the meaning of doing one's best. Quran commends people who endeavour to excel in what they do. 
Meanwhile, (Mukred Mohsen, 2007) defined Ihsan as the love of Allah which this love of Allah motivates the individual Muslim to work toward attaining Allah's pleasure. Prophet Muhammad SAW defined Ihsan as:

"To worship Allah as if you see Him, and if you cannot achieve this state of devotion, then you must consider that He is looking at you"'(Sahih Bukhari).

Ihsan is an essential operational principle for effective leadership. To being aware of the presence of Allah and that he is overseeing all what we do, Ihsan require a leader to endeavour to do his or her best (Haleem, 2004).

\subsubsection{Taqwa}

Taqwa is all-encompassing, inner consciousness of one's duty toward Him and the awareness of one's accountability toward Him (Beekun \& Badawi, 2004). According to Mukred Mohsen (2007), the root of Taqwa in the Arabic language is waka which means to protect or avoid or reserve. Taqwa is conceptualized as a state of complete maturity in which mind, heart and body are joined together, harmoniously and it is knowledge and behaviour. Whoever believes and observes Allah's guidelines in his private life as in his public life is a person with Taqwa (Mukred Mohsen, 2007). Taqwa will restrain a Muslim leader or follower from performing unjustly whether to community members or to anybody else (Ahmad \& Fontaine, 2011).

According to Haddara \& Ennany (2009), taqwa means humility which refer to being conscious of Allah's presence and fearing him all times. Taqwa makes a leader humble and more sincere at his work. The prophet of Islam set the flawless example of Taqwa by his deeds. Then, the four noble caliphs also practice modesty, humility and taqwa in their conducts.

\subsubsection{Amanah to Mankind}

There are four elements under the classification Amanah to Mankind which are Just, Responsibility, Integrity and Accountability (Harun, 2010; Mukred Mohsen, 2007).

\subsubsection{Just}

Just is an essential operational principle for effective leadership. Just in not only a fundamental construct in Islam but it also gives a safeguard that consideration turns into special favours to those who belong to the inner circle of a leader. Islam emphasizes the principle of just when they require making of judgement (Haleem, 2004).

Ayah 58, Surah An-Nisa emphasizes on one of the characteristics of a leader that is described by Allah which is being just or fair. This ayah depicts that by being just or fair, a leader is able to lead his followers toward betterment. In addition, based on Islamic teachings, the concept of Al-'Adalah means to have the strength of Imaan or faith and the ability to interpret Imaan into good practices in his or her leadership.

According to Randeree (2009), justice is a universal characteristic or trait and abandoning it means abandoning humanity. Hence, a leader should be just or fair in terms of economy, politics and social. Once a leader is not just or not being fair, it is then a sign of calamity to his or her leadership. A leader needs to make careful balance keeping the overall good of society in mind (Khan, 2014). Allah will show his wrath to those who become a traitor to being just (Kazmi \& Ahmad, 2006). 
"Indeed, Allah commands you to render trusts to whom they are due and when you judge between people to judge with justice. Excellent is that which Allah instructs you. Indeed, Allah is ever Hearing and Seeing. '(Surah An-Nisa: 58)

In addition, the Islamic way of life does not permit favouritism since it violates the ethical principles of justice (Al'Adl) and the right of others in dealings (Huquq Al'Ibad) (Ahmad \& Sadeq, 2001) as stated in Surah An-Nahl,

"Indeed, Allah orders justice and good conduct and giving to relatives and forbids immorality and bad conduct and oppression. He admonishes you that perhaps you will be reminded." (Surah An-Nahl: 90)

\subsubsection{Responsibility}

When we talk about responsibility, we talk about rights. In order for us to understand responsibility, we also need to understand rights. However, in this study, only responsibility is discussed. In term of definition, rights refer to something that you need to fulfill and responsibility refers to the things that you must carry out in fulfilling your needs. To illustrate, in the concept of domestic leadership, a husband has the rights to be met by his wife such as the rights to be respected, to be loved and be loyal to. The wife then has the responsibility to respect, love and be loyal to her husband as long as he does not go astray in obeying Allah's rules and regulations in life (Maudoodi, 2009).

Responsibility is the conscience of a person of his or her deliberate or undeliberate actions. Responsibility also means the conscience of a person's duties. According to the definition in encyclopedias, responsibilities are duties to be carried out by a person. Responsibilities can be classified into four dimensions which are being responsible toward one-self, being responsible toward family members, being responsible toward members of the society and being responsible toward the Creator (Awang, 2007).

\section{(a) One-Self}

Everybody is born pristine and without sins. Hence, it is one's life that shapes his or her actions as long as he or she lives. This is where responsibility toward one-self lies. The person is responsible for the choices that he or she makes in life. A person's existence is justified by how he or she leads the life as Allah's creation (Awang, 2007).

\section{(b) Family}

Similar to Allah's other creations mankind too instinctly produces offspring so that their history continues. In order to continue growing, mankind has to be responsible to their ancestery by providing them with the right protection and other necessary responsibilities such as marrying them off so that their families continue to have good values individually, to serve the society and Allah rightfully with those good values that they have gained through sharing and carrying out their responsibilities as family members. There are also instances in carrying out their responsibilities toward their family members in which they have to make sacrifices (Awang, 2007).

\section{(c) Society}

It is natural for a person to live with others; no man is an island. Mankind is the social creature; in order for a person to be human, he needs to communicate with others and learn how to live among others with being fully responsible toward each other (Awang, 2007). 
Allah creates mankind to serve Him and carry out that duty well. All of the actions taken by a person are accountable according to the rules and regulations of Allah as stated in the Quran. Allah reminds us of our actions that are against His rules and regulations through the Quran as well, and if mankind is persistent in disobeying His rules and regulations, Allah will show His wrath. It is our responsibility to carry out our duties so that Allah is contented with us and in doing this, we may have to make a lot of sacrifices (Awang, 2007).

Hence, in this study, carrying out the responsibilities toward the society and toward Allah in being a good leader is given emphasis. Allah SWT stated in His ayah which says:

"There has certainly come to you a Messenger from among yourselves. Grievous to him is what you suffer; [he is] concerned over you and to the believers is kind and merciful'(Surah at-Taubat: 128).

In addition, in the history of ulama', it was narrated that Umar bin Abdil Aziz in his tahajjud solah recited the ayahs of 22 to 24 from Ashshoffat Surah which stated:

"[The angels will be ordered], "Gather those who committed wrong, their kinds, and what they used to worship other than Allah, and guide them to the path of Hellfire And stop them; indeed, they are to be questioned."

The greater the leader, the bigger the responsibility extends. The concept of "circle of concern" dan "circle of influence" expounds by Covey in 1989 indicate that a true leader is someone who focuses on his circle of influence which affect the expansion of his influence into areas of concern. Unexpectedly, a leader who focuses upon his concern will see his influence diminish. Therefore, a great leader has a proactive sense of responsibility for those he leads which can be seen in Umar Bin Al Khattab (Monjur, 2010).

Umar often repeated those ayahs because he was thinking about the enormousity of the responsibilities of a leader when the leader has committed unjust actions in his leadership. Umar was famous with his words:

"Should a donkey slipped in the city of Baghdad, believe it! Umar is asked to be responsible and asked: Why is he not mending the road for the donkey?"

That are just two examples given by the Muslim scholars and devotees of how huge responsibilities of a leader are in carrying out his or her duty to meet Allah later.

\subsubsection{Integrity}

A leader's integrity is very much related to the image of Islam dan the fate of his followers and his family in this world and in the world hereafter. Prophet Muhammad (pbuh) who is seen as the most loving to his ummah was still thinking about them even in his last breath. This demonstrates that Prophet Muhammad is a person with integrity, and this integrity becomes the savior for mankind because it saves us from Allah's punishment. This is stated in a hadith narrated by Imam Bukhari,

"We, (Muhammad's ummah) are the last (to dwell the earth) but the first to be judged on the Judgement Day. We are the ones who first enter paradise despite they are the ones who have been given the Books first and we are later than them"

Leadership with integrity in a community is an excellent leadership. This is given emphasis by Allah in the Quran in Surah of Al-Baqarah, ayah 124 which stated: 
"And [mention, O Muhammad], when Abraham was tried by his Lord with commands and he fulfilled them. [ Allah ] said, "Indeed, I will make you a leader for the people. "[Abraham] said, "And of my descendants?" [ Allah ] said, "My covenant does not include the wrongdoers" (Surah Al-Baqarah:124).

A leader must enhance his self-quality and integrity by taking Prophet Muhammad (pbuh) and his companions as excellent examples. This can be done in several ways. Among them is to strengthen the management of the country dan the community based on the syariah of Islam, to disregard corrupt leaders and we have to remember that a corrupt leader should not be taken as an example since he or she has no integrity. Even though in this world he or she can escape the law, nobody can escape the punishment from Allah on the Judgement Day. A leader who has integrity will be respected and loved by fellow subjects. As Allah SWT mentions in Surah of Al-Saff ayahs 2-3 which states,

"O you who have believed, why do you say what you do not do? Great is hatred in the sight of Allah that you say what you do not do"(Surah Al-Saff: 2-3).

\subsubsection{Accountability}

Accountability is a vital component for the leadership process (Syed Agil, 1994). From the perspective of Islam, accountablity means each person has his or her duties to be carried out and he or she is fully responsible for all actions and accountable to Allah SWT, the Creator (Ather \& Sobhani, 2008). The more a person is closer to Allah SWT, the more he will know-how admiration and promise from his followers. If anything goes wrong, he should take full liability of the happenings and challenges to cure the state of affairs and does not put the blame on anyone else (Jamil, 2015). This is mentioned in Az-Zilzal Surah, ayahs 7-8,

"So whoever does an atom's weight of good will see it, And whoever does an atom's weight of evil will see it." (Surah Al-Zilzal:7-8).

A leader is mostly accountable for his deeds and is bound to be accountable to his followers and Allah SWT. As stated by Prophet Muhammad:

"Each of you is a shepherd and each of you is responsible of his flock. The Amir (ruler) who is over the people is a shepherd and is responsible for his flock" (Hadith Imam Abu Daud).

Accountability can be classified into three dimensions which are personal accountability, limited accountability and leadership accountability (Syed Agil, 1994) which are described in Table 2. In this study, the dimension of accountability that will be discussed is leadership accountability.

Table 1. Dimensions of Accountability

\begin{tabular}{|c|l|}
\hline Dimension & \multicolumn{1}{|c|}{ Description } \\
\hline Personal & $\begin{array}{l}\text { Each person is responsible in carrying out his or her duty that is ordered } \\
\text { by Allah SWT as regulated in the Quran and Hadiths. Hence, a person } \\
\text { could not blame someone else for his or her actions, whether the } \\
\text { actions are right or wrong. }\end{array}$ \\
\hline Limited & $\begin{array}{l}\text { Even though each person is accountable in his or her actions, Allah } \\
\text { knows that a person has a certain limit and He does not make His } \\
\text { servants be accountable for all the actions that are beyond His servants' } \\
\text { capabilities or abilities. }\end{array}$ \\
\hline
\end{tabular}




\begin{tabular}{|l|l|}
\hline \multicolumn{1}{|c|}{ Leadership } & $\begin{array}{l}\text { This accountability is everyone’s share since everyone is a leader despite } \\
\text { of what he or she does for living. Personal and leadership accountability } \\
\text { are interrelated; personal accountablility will enhance leadership } \\
\text { accountability. }\end{array}$ \\
\hline
\end{tabular}

\subsubsection{Leadership Accountability}

Leadership accountability requires several matters (Monjur, 2010). Among them are leaders must place individuals under his supervision according to the categories of trustworthiness and the individuals' capabilities. It is unfair for the individuals to be placed not according to their capabilities as this translates into their failure in being accountable to Allah for not carrying out their duties well. This will also affect the society's well-being. Leader accountability also ensures that a leader will not be a dictator but will have consensus from his or her fellow subordinates in making decisions. By having leadership accountability, a leader will also set a good example to his fellow subordinates so that all his actions and decisions will be accepted by them.

\section{Conclusion}

All in all, it can be said that trustworthiness is the core of leadership. A leader's success depends on his or her ability to carry out his duties according to what Allah has outlined in the Quran. A leader should be trustworthy since trust is a moral responsibility for everyone in the performance of their duties and their social, political and economic lives (Hanafi \& Sallam, 2006). It is a core value which fits within an overall Islamic etiquette governing social relationships (Alabed, 2017). A leader will be rewarded paradise as promised by Allah if he or she is able to lead the followers to the path that Allah wills and a leader is practicing a sunnah when he or she manages and administers his or her leadership due to Allah.

By being trustworthy, the individual not only fulfils Allah's SWT command but can perform good attitudes that will be accepted universally by everyone and can perform the tasks and duties given transparently which gives better perception and building trust in the individual. This paper also suggests that more research is needed in identifying more elements for trustworthiness in leadership.

\section{Acknowledgement}

The authors gratefully acknowledge the financial support from UTM of Vot 19H08 and 12H17.

\section{References}

Abidin, D.Z. (2008). 7 Formula Individu Cemerlang. Kuala Lumpur: PTS Millenia Sdn Bhd.

Ahmad, K. \& Fontaine, R. (2011). Islamic. Leadership At The International Islamic University Malaysia. International Journal of Economics, Management and Accounting 9(2), 121-135.

Ahmad, K. \&. Sadeq, A. H. M. (2001). Islamic ethics in a changing environment for managers in Ahmad, K. and Sadeq, A.H.M. (Eds), Ethics in Business and Management Islamic and Mainstream Approaches, Asean Academic Press, Subang Jaya.

Al-Mawardiy, A. AH. A. (1993). Al-Ahkam Al-Sultaniyyah Wa Al-Wilayah Al-Diniyyah (Hukum-Hukum Pemerintahan Dan Kekuasaan Agama). Kuala Lumpur :Institut Pengajian Tradisional Islam.

Alabed, M. (2017). Exploring the Islamic principles on leadership and its implementation between Muslim leaders in Sweden. Master Thesis. Chalmers University of Technology. 
Ather, S. M. \& Sobhani, F. A. (2008). Managerial Leadership : An Islamic Perspective. IIUC Studies 4, 7-24.

Awang, A. H. (2007). Takwa: Takut Tapi Rindu. Selangor: PTS Publications \& Distributors Sdn Bhd.

Beekun, R. I. \& Badawi, J. (2004). Leadership An Islamic Perspective. USA: Amana Publications.

Haddara, M. \& Ennany, F. (2009). Leadership An Islamic Perspective.

Haleem, A. (2004). The Qur'an, A New Translation. London :Oxford.

Hanafi, M. \& Sallam, B. (2006). Perspectives on Islam and Management, Working Paper No. 141, International Islamic University, Kuala Lumpur.

Harun, H. (2013). Al-Quwwah dan Amanah Teras Kepimpinan Islam Masa Kini. Arkib Harakah Daily.

Jamil, M. Y. (2015). Islamic Perspective of Leadership: A Role Model for Today's CEOs. Journal of Islamic Thought and Civilization 5 (2), 25-45.

Kazmi, A. \& Ahmad, K. (2006). Management from Islamic perspective. Instructors' Resource Manual, International Islamic University, Kuala Lumpur.

Khan, A. (2014). Islamic Leadership Principle (A Success Model For Everyone And All Times). Islamic Research Foundation International.

Khan, B., Farooq, A., \& Hussain, Z. (2010). Human Resource Management: An Islamic Perspective. Asia-Pasific Journal of Business Administration 2, 17-34.

Maudoodi, S. A. A'la. (2009). The Rights and Duties of Spouse. New Delhi: Markazi Maktaba Islami Publisher.

Monjur, M. (2010). Characteristics of Leadership :Islamic Perspective. Research Gate.

Mukred Mohsen, N. R. (2007). Leadership From The Quran Relationship Between Taqwa, Trust and Business Leadership Effectiveness.

Randeree, K.. (2009). An Islamic Perspective on Leadership: Qur'anic View on the Qualities of Leaders. The Global Studies Journal, 2(1), 197-210.

Syed Agil, S. O. (1994). Sistem Akauntabiliti Dalam Pengurusan Islam. Institut Perkembangan Minda.

Zainal Abidin, M. A. (2010). Mengemudi Bahtera Perubahan Minda. Utusan Publications \& Distributor Sdn Bhd. 